\title{
Interest Rate and Inflation Nexus, an Application of Granger Causality Test Empirical Investigation: A Case Study of UK
}

\author{
Saad Uddin Khan ${ }^{*}$ \\ Ph. D Student, Department of Economics, University of Karachi, Pakistan
}

\begin{abstract}
DOI: $10.36348 /$ sjbms.2020.v05i01.005
| Received: 20.11.2019 | Accepted: 27.11.2019 | Published: 19.01 .2020

*Corresponding author: Saad Uddin Khan

Abstract

The study is an application of VAR Granger Causality test on time series data. It conducted on United Kingdom (UK) annual data from 1989 to 2017. The time-series analysis used. Both formal and informal method is used to determine the stationary level. For regression analysis, Vector Autoregression model and Johnson cointegration equation used. The result found that interest rate and inflation are stationary at first difference, i.e. I(1). VAR Granger causality test between inflation and interest rate found that there is bilateral causality among these variables.
\end{abstract}

Keywords: Interest rate, inflation rate, VAR, Granger causality, UK.

Copyright @ 2020: This is an open-access article distributed under the terms of the Creative Commons Attribution license which permits unrestricted use, distribution, and reproduction in any medium for non-commercial use (NonCommercial, or CC-BY-NC) provided the original author and source are credited.

\section{INTRODUCTION}

Economics is a positive science that expresses the nature of relationship between different variable and discusses cause and effect among variable. Current study discusses the relationship between interest and inflation as both macroeconomic variables are vital to study and highly correlated in an economy. Leiderman and Svensson [1]; Bernanke et al., [2] suggest that Policymakers, investors and consumer are always keen to study the relation and causality among interest rate and inflation.Thus, exact prediction of inflation helps monetary policymakers to implement interest rate to meet the target inflation in the economy Bernanke, et al., [2]. So, this study is an important one for investor, policymaker, consumer and other stake holder in context of UK economy and it would also an important addition to empirical literature.

Generally, the Interest rate is the amount paid or received over the amount of money lent or borrowed. Economics defines interest rate as the price of credit. Law of supply and demand for money set the interest rate in the free market. Various thought had been put forward to explain the concept of interest rate. Payment of interest is the benefits to the borrower and receiving interest is the premium on risk of default received by lender this thought given by school of Salamanca. Later time preference is added to the concept of interest rate by Martin de Azpilcueta in sixteen century. Robert and Baron explain the concept of interest rate with opportunity cost.

Karl Marx argues that the interest rate not derived by market forces other social sectors are also included in deriving the value of interest rate. Other economists, like Adam Smith, Frederic, Irving Fisher and John Maynard Keynes also proposed their theories to explain the concept of interest rate. Interest rates can be influenced (increase or decrease) by monetary policy, fiscal policy, exchange rate fluctuation, maturity period and supply and demand of money and other factors. Interest rate is one of the strongest tool to control monetary policy. Generally by the word interest rate we mean interest rate spread which is calculated by difference between lending rate and borrowing rate. The Real interest rate is the inflation-adjusted interest rate. The interest rate in UK is set by Bank of England through monetary policy committee, and termed as 'Bank Rate'. It is also known as base rate, it is the amount of interest paid on the reserve kept in Bank of England by other commercial bank. So, it is only lower limit set by Bank of England. The bank of England set this rate by keeping in view to inflation target policy 
which normally taken at $2 \%$. Currently, Bank of England sest interest rate value to $0.5 \%$ the borrowing rate or prime interest rate currently is $1.25 \%$ for the year 2018 . It is the $16 \%$ lower than the previous year's value of $1.5 \%$. According to the Bank of England, bank interest rate decline due to lower growth rate. In current study, we take nominal prime interest rate from 1989 to 2017 as a proxy for interest rate.

Inflation, one of the vital macroeconomic indicators generally defines as "General increase in price level of goods and services". In economics, inflation defines as the increase or decrease of power of money (currency) to buy goods and services between two periods. In other words, Inflation referred to enhancement in amount of money in circulation. In today's world word inflation is used to show the change in price level. But these two things are different inflation due to increase in money supply termed as monetary inflation while inflation due to increase in price level of goods and serves termed as price inflation. Most economists believe inflation due to money supply prevails longer period.

Inflation rate can be influenced by both monetary and fiscal policy. A massive amount of economic literature was found discussing the inflation, its causes and its effect. The literature found can be classified into two broad categories quantity theory of inflation and quality theory of inflation. The quantity theory of inflation purposed by Adam Smith and David Hume's based on supply of money, velocity of money and nominal exchange rate while quality theory based on expectation of buyer and seller. In today's world, there is consensus found among the economist that quantity theory of inflation found accepted in long run. While short-run factor describes by Keynes such as relative price, wage and interest rate also influence inflation rate.

According to triangle model, purposed by R.J. Gordon inflation can be classified into three main categories: First; Demand-pull inflation due to expansionary fiscal policy, i.e. rise in government spending or reduction in taxation. Second; cost-push inflation due to sudden fall in aggregate supply it is also known as supply shock inflation. Third, the built-in inflation or hangover inflation in which labour strive to put their wage above the inflation rate; as a result, the burden of increased cost is transferred by firm to customer as a higher prices of goods. There are lots of methods to calculate inflation such as base year method, weighted average method, chain base method, Passchen index, Laysper index, Fisher index and Marshall index are the few. In England, inflation was measured by Office for National Statistics (ONS). The inflation measured by ONS is the actual inflation prevail in the economy which is based on the basket of goods. The inflation rate calculated by ONS every month compared by inflation target set by Bank of England. Currently inflation rate is $2.4 \%$ while the inflation target is $2 \%$. It means actual inflation is higher than the inflation target. The monetary policy committee will now take action to meet the target inflation currently they have declined the interest rate to catch up the targeted value. In current study we take average annual value of actual inflation measured by ONS from 1989 to 2017as a proxy of inflation.

The empirical analysis done by employing time series analysis. First to check the stationary among the variable unit root and correlogram is used to determine the stationary level. To predict the direction of influence Granger causality test is employed. Result found using the VAR model estimate because interest and inflation are stationary at first difference obtained through formal and informal stationary test while VAR Granger causality test found that inflation and interest rate are bilateral causal variables.

The objective of the study is to investigate the causality between the interest rate and inflation for the data of United Kingdom for the period 1989 to 2017. This study is different from the previous relevant studies in term of data, technique and objective.

\section{LITERATURE REVIEW}

Many of theoretical and empirical literature found in text discussing the relationship of interest rate and inflation on different data set or with different technique. Relationship and causality between interest rate and inflation were the burning issue over decades among the researcher. It's all started from the Fisher hypothesis in 1930 . He proposed nominal interest rate is the sum of inflation and real interest rate. Further he incorporates the idea that price change in the previous period can reflect in current interest rate. Many researchers adopted the Fisher idea to explain their different objectives such as Cagan [3]. Fisher hypothesis verifies by Sargent [4] and Gibson [5]. They add up lag variable of inflation in the Fisher model. The important conclusion found by these researchers was that policy which designed to influence interest rate indirectly influence price. Alternative views of Fisher hypothesis were present in the theory of rational expectation present by Muth [6] and Fama [7]. They suggested that future price changes reflected in the current interest rate. These views supported by Lee [8], Levi and Makin [9]. Joines [10], Nelson and Schwert [11] while Hess and Bicksler [25] used a different approach to forecast inflation empirically found insignificant effect on interest rate.

Carlson [12] using 1953 to 1971 data set reject the Fama's view by adding employment to population lag variable to Fama's model. Empirical result found is a significant result. Carlson concludes that not only inflation another variable also influence interest rate. 
Saad Uddin Khan; Saudi J Bus Manag Stud, Jan., 2020; 5(1): 32-39

Mishkin [13] studied Fisher model on six countries UK, USA, Germany, Netherlands, Canada and Switzerland from 1967 to 1979 and found positive significant relation between nominal interest rate and inflation for UK,USA and Canada while weak effect in case of Germany, Netherland and Switzerland.

MacDonald and Murphy [14] used data of USA, U.K, Belgium and Canada for the period 1955 to1986 to verify Fisher hypothesis with the dummy variable of exchange rate regime. The result found to be existence of Fisher hypothesis in UK and Belgium while insignificant result found in case of USA and Canada in presence of flexible exchange rate.

Mishkin [15] studied Fisher hypothesis under time series analysis. The empirical result found that inflation and interest rate are stochastic trends means that the interest rate can be forecast through inflation. He used monthly data from 1953 to 1990 . Time series analysis done through DF and Phillips tests. The result indicated one cointegration between inflation and interest rates. In other words, long-run relationship revealed between the interest rate and inflation.

Wallace and Warner [16] used an expectations model to examine long run, and short-run relationship and Johansen cointegration test applied on 1948.Q11990.Q4, and found interest and inflation rates to be I(1). These result obtained are similar to Miskin [15].

Mishkin, Peng [17] used Johassen and Jeselius [18] cointegration technique on time series data set for 1957-1994 of interest and inflation of France, UK and USA. The empirical result found a long-run positive relationship between interest rates and inflation. Rose [19] used annual data of inflation and interest rate of the USA. Empirically found that inflation is stationary at level, i.e. I (0) and interest rate is stationary at first difference, i.e. I (1). He found positive relationship between inflation and interest rate.

Paul et al., [20] analyzes the effect of the nominal exchange rate, Inflation rate, capital stock and foreign direct Investment on economic growth in Kuwait by using time series data for the period of 19752015. The results confirm that as nominal exchange rate increases then it lead to a significant positive effect on economic growth. Similarly, Mustafa and Rashid [21] find a negative effect of exchange rate volatility on different macroeconomic variables in Pakistan. Abbas, S. K et al., [22] analyzes the effect of the revaluation of fixed assets on future performance of firms in Pakistan. They analyzes the cement sector of Pakistan. Results revealed that revaluation of fixed assets puts a negative impact on future firm performance in cement companies. Saad Khan and Rashid Ali [23] studied the relationship between export demand and exchange rate volatility in Pakistan. They employed autoregressive distributed lag model (Bound test). The result confirms that the real effective exchange rate has an insignificant negative effect on aggregate export demand of Pakistan.

\section{HYPOTHESIS}

The two hypothesis used in the current study are

\section{First Hypothesis}

Null hypothesis Ho: Inflation does not Granger

Cause interest rate

Alternate hypothesis Ha: Inflation Granger

Cause interest rate

\section{Second Hypothesis}

Null hypothesis Ho: Interest rate does not Granger Cause Inflation

Alternate hypothesis Ha: Interest rate Granger Cause Inflation

\section{METHODOLOGY}

Model 1 explains the influence of interest rate on inflation. Equation 1(a) explains that interest rate $\left(\mathrm{IR}_{\mathrm{t}}\right)$ at time $t$ is depending upon the value of inflation $\left(\operatorname{Inf}_{\mathrm{t}-1}\right)$ at time $\left(\mathrm{t}_{-1}\right)$ that is the previous year value. Similarly in equation 1(b) explains that interest rate $\left(\mathrm{IR}_{\mathrm{t}}\right)$ at time $t$ is depending upon the value of inflation of previous two years i.e. $\operatorname{Inf}_{\mathrm{t}-1}$ and $\mathrm{Inf}_{\mathrm{t}-2}$. Similarly equation 1(c) interest rate $\left(\mathrm{IR}_{\mathrm{t}}\right)$ at time $t$ is related to previous value of interest rate (itself) and previous values of inflation. In current study, equation 1(c) is used to estimate the influence of inflation at $(\mathrm{t}-\mathrm{i})$ period on interest rate at time $t$.

$$
\begin{aligned}
& \text { Model 1: } \\
& I R_{t}=a_{0}+a_{1} \operatorname{Inf}_{t-1}+U_{1} \ldots \ldots . . . \text { equation } 1(a) \\
& I R_{t}=a_{0}+a_{1} \inf _{t-1}+a_{2} \inf _{t-2}+U_{1} \ldots \ldots . . . \text { equation } 1(b) \\
& I R_{t}=\sum_{i=1}^{n} \alpha_{i} I n f_{t-i}+\sum_{j=1}^{n} \beta_{j} I R_{t-j}+U_{1_{t}} \ldots \ldots . . \text { equation } \\
& \text { 1(c) }
\end{aligned}
$$

Here: IR represents the logarithm value of interest rate Inf represents logarithm value of inflation. i represent the lag term involve it can i $\epsilon \mathrm{N}$

As the above mention model is in log-log form, the coefficient represents the elasticity. The expected the sign of $\alpha_{i}<0$ i.e negative.

Similarly, model 2 explains the influence of interest rate on inflation. Equation 2(a) explains that inflation $\left(\operatorname{Inf}_{t}\right)$ at time $t$ is depending upon the value of interest rate $\left(\mathrm{IR}_{\mathrm{t}-1}\right)$ at time $\left(\mathrm{t}_{-1}\right)$ that is the previous year value. Similarly in equation 2(b) explains that inflation $\left(\operatorname{Inf}_{t}\right)$ at time $t$ is depending upon the value of interest rate of the previous two years, i.e. $I_{t-1}$ and $I_{t-2}$. Similarly equation 2(c) inflation $\left(\operatorname{Inf}_{t}\right)$ at time $t$ is dependent on previous values of itself as well as interest rate. In current study equation 2(c) is used to estimate the influence of interest rate at $(\mathrm{t}-\mathrm{j})$ period on inflation at time $\mathrm{t}$. 
Model 2:

$\operatorname{Inf}_{t}=b_{0}+b_{1} I R_{t-1}+U_{2} \ldots \ldots . .2(a)$

$\operatorname{Inf}_{t}=b_{0}+b_{1} I R_{t-1}+b_{2} I R_{t-2}+U_{2} \ldots \ldots . .2(b)$

$I n f_{t}=\sum_{j=1}^{n} \gamma_{j} I R_{t-j}+\sum_{i=1}^{n} \delta_{i} I n f_{t-i}+U_{2_{t}} \ldots \ldots . .2(c)$

Here: Inf represents the logarithm value of interest rate

IR represents the logarithm value of inflation. $\mathrm{j}$ represents the lag term involve it can $\mathrm{j} \epsilon \mathrm{N}$

As the above mention model is in log-log form, the coefficient represent the elasticity

\section{MATERIAL AND METHODS}

The current study is based on time series data (1989 to 2017) of interest rate and inflation rate of United Kingdom (UK). Interest rate is proxy by prime interest rate which is also known as borrowing interest rate. Inflation rate is proxy by CPI. The date is extracted from the bank of England web site. The descriptive statistics is presented in Table-1.

Table-1: Statistical description of interest Rate (IR) and inflation Rate (INF)

\begin{tabular}{|l|l|l|}
\hline \multicolumn{2}{|c}{ inflation Rate (INF) } \\
\hline Mean & IR & INF \\
\hline Median & 5.939655 & 2.534351 \\
\hline Maximum & 6.200000 & 2.166231 \\
\hline Minimum & 15.80000 & 7.532649 \\
\hline Std. Dev. & 1.250000 & 0.050021 \\
\hline Skewness & 4.084889 & 1.748832 \\
\hline Kurtosis & 0.837080 & 1.394709 \\
\hline Jarque-Bera & 3.269158 & 4.613562 \\
\hline Probability & 3.474268 & 12.54786 \\
\hline Sum & 0.176024 & 0.001885 \\
\hline Observations & 172.2500 & 73.49617 \\
\hline
\end{tabular}

Source: Author's Calculation

\section{EMPIRICAL ANALYSIS}

Causality test is formulated by Clive Granger in 1969. He worked on causality among different variables. He prpposed bi-variant granger causality test and multivariat causality test. In current study, bivariat granger is explained multivariat granger causality does not explain here because it is beyond the approach of current study. If the time series variables are not stationary at level than granger causality will not be used directly. Initially we make the variable stationary and this can be done by two ways first is informally or weak stationary test secondly through formal way. To predict stationary through informal way graph of auto correlation at various lags i.e. correlogram test is applied. Formally stationary would be checked by obtaining whether the time series containing a unit root. For this purpose, Dickey fuller test (DF) and augmented Dickey fuller test were used. After obtaining the stationary level, vector auto regression estimate would be applied. After applying the VAR-estimates vector auto regression, Granger causality test applied to predict the direction of influence among the variable.

\section{RESULTS AND DISCUSSION}

First we check stationary informally. To do so the variable of interest rate and inflation are not stationary at level both informal and formal test conclude that both these variable are stationary at level. The summary of the result is in Table-2.

Table-2: Summary for Stationarity

\begin{tabular}{|c|c|}
\hline Time series & Stationary level \\
\hline Interest rate (IR) & $\mathrm{I}(1)$ \\
\hline Inflation(INF) & $\mathrm{I}(1)$ \\
\hline
\end{tabular}

Source: Author's Calculation

Secondly we check stationary formally. For this purpose the augmented Dickey Fuller test is used for formal test for stationary the result at first difference is shown in Table-3. It support the informal test result obtained from correlogram test. Both variables are stationary at first difference so unrestricted VAR model is used.

Table-3: Formal test of stationary check (unit root test at first difference)

\begin{tabular}{|c|c|c|c|c|}
\hline \multicolumn{3}{|c|}{ Method } & Statistic & Prob.** \\
\hline \multicolumn{3}{|c|}{ ADF - Fisher Chi-square } & 30.7659 & 0.0000 \\
\hline \multicolumn{3}{|c|}{ ADF - Choi Z-stat } & -4.68911 & 0.0000 \\
\hline \multicolumn{5}{|c|}{ Intermediate ADF test results D(UNTITLED) } \\
\hline Series & Prob. & Lag & Max Lag & Obs \\
\hline $\mathrm{D}(\mathrm{IR})$ & 0.0004 & 0 & 5 & 27 \\
\hline $\mathrm{D}$ (INF) & 0.0005 & 1 & 5 & 26 \\
\hline
\end{tabular}

Source: Author's Calculation

Thirdly, we apply VAR. For this purpose the result obtained by using VAR model. Result is show in Table-4 with 2 lags and Table-5 with 4 lags respectively while executing these model intercept (trend) is used as exogenous variable.

Table-4: Vector Auto Regression Estimates for two lags

\begin{tabular}{|l|c|c|}
\hline \multicolumn{3}{|c|}{ Sample (adjusted): 19912017} \\
\hline \multicolumn{3}{|c|}{ Standard errors in ( ) \& t-statistics in [ ] } \\
\hline & INF & IR \\
\hline INF(-1) & 0.450636 & -0.068818 \\
\hline & $(0.21083)$ & $(0.08181)$ \\
\hline & {$[2.13745]$} & {$[-0.84115]$} \\
\hline INF(-2) & -0.083910 & 0.046016 \\
\hline & $(0.21174)$ & $(0.08217)$ \\
\hline & {$[-0.39628]$} & {$[0.56002]$} \\
\hline IR(-1) & -0.115777 & 0.990472 \\
\hline & $(0.54129)$ & $(0.21006)$ \\
\hline & {$[-0.21389]$} & {$[4.71529]$} \\
\hline IR(-2) & 0.356346 & -0.060223 \\
\hline & $(0.55526)$ & $(0.21548)$ \\
\hline C & {$[0.64176]$} & {$[-0.27949]$} \\
\hline & -0.019356 & 0.011815 \\
\hline & $(0.15801)$ & $(0.06132)$ \\
\hline R-squared & {$[-0.12250]$} & {$[0.19269]$} \\
\hline Adj. R-squared & 0.294972 & 0.860340 \\
\hline & 0.166785 & 0.834948 \\
\hline
\end{tabular}

Source: Author's Calculation

Table-5: Vector Auto regression Estimates for four lags 
Saad Uddin Khan; Saudi J Bus Manag Stud, Jan., 2020; 5(1): 32-39

\begin{tabular}{|l|c|c|}
\hline \multicolumn{3}{|c|}{ Included observations: 25 after adjustments } \\
\hline \multicolumn{3}{|c|}{ Standard errors in ( ) \& t-statistics in [ ] } \\
\hline & IR & INF \\
\hline IR(-1) & 1.007628 & -0.745348 \\
\hline & $(0.24931)$ & $(0.51371)$ \\
\hline & {$[4.04161]$} & {$[-1.45092]$} \\
\hline IR(-2) & -0.415605 & 0.781573 \\
\hline & $(0.37219)$ & $(0.76689)$ \\
\hline & {$[-1.11665]$} & {$[1.01914]$} \\
\hline IR(-3) & 0.404330 & -1.250476 \\
\hline & $(0.42905)$ & $(0.88405)$ \\
\hline & {$[0.94238]$} & {$[-1.41448]$} \\
\hline IR(-4) & -0.076288 & 1.739434 \\
\hline & $(0.32366)$ & $(0.66689)$ \\
\hline & {$[-0.23571]$} & {$[2.60828]$} \\
\hline INF(-1) & -0.074798 & 0.145620 \\
\hline & $(0.09992)$ & $(0.20588)$ \\
\hline & {$[-0.74857]$} & {$[0.70729]$} \\
\hline INF(-2) & 0.136321 & -0.420995 \\
\hline & $(0.11899)$ & $(0.24517)$ \\
\hline & {$[1.14568]$} & {$[-1.71714]$} \\
\hline INF(-3) & -0.400177 & 1.782481 \\
\hline & $(0.35325)$ & $(0.72786)$ \\
\hline & {$[-1.13285]$} & {$[2.44892]$} \\
\hline INF(-4) & 0.217479 & -1.740442 \\
\hline & $(0.29249)$ & $(0.60268)$ \\
\hline & {$[0.74353]$} & {$[-2.88783]$} \\
\hline C & 0.044454 & -0.146838 \\
\hline & $(0.09452)$ & $(0.19475)$ \\
\hline & {$[0.47033]$} & {$[-0.75399]$} \\
\hline R-squared & 0.854671 & 0.550077 \\
\hline Adj. R-squared & 0.782007 & 0.325116 \\
\hline & & \\
\hline & &
\end{tabular}

Source: Author's Calculation

Fourth, to predict the direction of causality that is our main objective, granger causality is applied. The
Table 6 and 7 present VAR Granger causality test result on 2 lags and 4 lags respectively.

Table-6: VAR Granger Causality/Block Exogeneity Wald Tests

\begin{tabular}{|c|c|c|c|}
\hline \multicolumn{2}{|c|}{ Sample: 19892017} & & \\
\hline \multicolumn{3}{|c|}{ Included observations: 27} & \\
\hline \multicolumn{3}{|c|}{ Dependent variable: INF } & \\
\hline Excluded & Chi-sq & df & Prob. \\
\hline IR & 1.243262 & 2 & 0.5371 \\
\hline All & 1.243262 & 2 & 0.5371 \\
\hline \multicolumn{3}{|c|}{ Dependent variable: IR } & \\
\hline Excluded & Chi-sq & $\mathrm{df}$ & Prob. \\
\hline INF & 0.742557 & 2 & 0.6899 \\
\hline All & 0.742557 & 2 & 0.6899 \\
\hline
\end{tabular}

Source: Author's Calculation

Table-7: VAR Granger Causality/Block Exogeneity Wald Tests for four lags

\begin{tabular}{|l|l|l|l|}
\hline \multicolumn{2}{|l|}{ Sample: 1989 2017 } & & \\
\hline \multicolumn{3}{|l|}{ Included observations: 25} & \\
\hline Dependent variable: IR & \\
\hline Excluded & Chi-sq & df & Prob. \\
\hline INF & 2.639810 & 4 & 0.6198 \\
\hline All & 2.639810 & 4 & 0.6198 \\
\hline Dependent variable: INF & \\
\hline Excluded & Chi-sq & df & Prob. \\
\hline IR & 10.13095 & 4 & 0.0383 \\
\hline All & 10.13095 & 4 & 0.0383 \\
\hline
\end{tabular}

Source: Author's Calculation

The lag criteria is chosen though lag structure test. The lag criteria are important because Granger causality test is sensitive to the number of lags used in the model. The result is presented in Table-8.

Table-8: Test for lag selection criteria

\begin{tabular}{|l|l|l|l|l|l|l|}
\hline Lag & LogL & LR & FPE & AIC & SC & HQ \\
\hline 0 & -16.04849 & NA & 0.014526 & 1.443879 & 1.541390 & 1.470925 \\
\hline 1 & 8.261129 & 0.937029 & 0.003801 & 0.092258 & 0.579809 & 0.227484 \\
\hline 2 & 8.846772 & $42.78493 *$ & $0.002867 *$ & $-0.180890 *$ & $0.111640 *$ & $-0.099755^{*}$ \\
\hline 3 & 11.46094 & 3.764406 & 0.004331 & 0.203125 & 0.885695 & 0.392441 \\
\hline 4 & 17.76669 & 8.071360 & 0.003737 & 0.018665 & 0.896255 & 0.262071 \\
\hline$*$ * indicates lag order selected by the criterion & & & \\
\hline \multicolumn{7}{|l|}{ Sor } \\
\hline
\end{tabular}

Source: Author's Calculation

The summary of lag selection criteria present in Table-9:

Table-9: Summary of Result for Lag Selection Criteria

\begin{tabular}{|l|l|}
\hline Name of Criteria & No of lag \\
\hline Squential modified LR test statistic & 2 \\
\hline Final prediction error & 2 \\
\hline Akaike information criterion & 2 \\
\hline Schwarz information criterion & 2 \\
\hline Hannan-Quinn information criterion & 2 \\
\hline
\end{tabular}

Source: Author's Calculation

The summary of VAR Granger Causality test is shown in table 10 . We present below the result of chi- square statistic and probability to decide whether to reject or do not reject. 
Table-10: Summary of Result for Var Granger Causality Test

\begin{tabular}{|l|l|l|l|l|l|l|}
\hline Null Hypothesis(Ho) & $\begin{array}{l}\text { Direction of } \\
\text { causality }\end{array}$ & $\begin{array}{l}\text { No. of } \\
\text { lags }\end{array}$ & $\begin{array}{l}\text { Chi - } \\
\text { square }\end{array}$ & Probability & Result & Conclusion \\
\hline $\begin{array}{l}\text { INF does not Granger } \\
\text { Cause IR }\end{array}$ & Inf $\rightarrow$ IR & 2 & 0.7425 & 0.689 & Reject Ho & Inf Granger cause IR \\
\hline $\begin{array}{l}\text { IR does not Granger } \\
\text { Cause INF }\end{array}$ & IR $\rightarrow$ Inf & 2 & 1.243 & 0.537 & Reject Ho & IR Granger cause Inf \\
\hline $\begin{array}{l}\text { INF does not Granger } \\
\text { Cause IR }\end{array}$ & Inf $\rightarrow$ IR & 4 & 2.639 & 0.619 & Reject Ho & Inf Granger cause IR \\
\hline $\begin{array}{l}\text { IR does not Granger } \\
\text { Cause INF }\end{array}$ & IR $\rightarrow$ Inf & 4 & 10.13 & 0.038 & $\begin{array}{l}\text { Do not } \\
\text { Reject Ho }\end{array}$ & $\begin{array}{l}\text { IR does not Granger } \\
\text { Cause INF }\end{array}$ \\
\hline
\end{tabular}

Source: Author's Calculation

From above exercise, we conclude that there are bilateral causality between interest rate and inflation. However at four lags there is unidirectional causality i.e. inflation cause interest rate only there is no reverse causality while including four lags.
Further to support, the empirical results of Granger causality test, impulse response with different dependent variable is shown in the figure1. Johnsen cointegration result is presented in Table-11, confirm the one cointegration equation these result resemble with Mishkin, Peng [24].

Table-11: Johnson Cointegration test

\begin{tabular}{|c|c|c|c|c|}
\hline Hypothesized & & Trace & 0.05 & \\
\hline No. of $\mathrm{CE}(\mathrm{s})$ & Eigenvalue & Statistic & Critical Value & Prob.** \\
\hline None $*$ & 0.622550 & 21.98993 & 15.49471 & 0.0046 \\
\hline At most 1 & 0.024911 & 0.554974 & 3.841466 & 0.4563 \\
\hline Hypothesized & & Max-Eigen & 0.05 & \\
\hline No. of $\mathrm{CE}(\mathrm{s})$ & Eigenvalue & Statistic & Critical Value & Prob.** \\
\hline None $*$ & 0.622550 & 21.43496 & 14.26460 & 0.0031 \\
\hline At most 1 & 0.024911 & 0.554974 & 3.841466 & 0.4563 \\
\hline IR & INF & & & \\
\hline-10.54059 & 15.45113 & & & \\
\hline 11.93245 & -1.971075 & & & \\
\hline \multicolumn{5}{|c|}{ Unrestricted Adjustment Coefficients (alpha): } \\
\hline $\mathrm{D}(\mathrm{IR})$ & -0.085677 & 0.001222 & & \\
\hline $\mathrm{D}(\mathrm{INF})$ & -0.066504 & 0.021496 & & \\
\hline \multicolumn{2}{|c|}{1 Cointegrating Equation(s): } & Log likelihood & 41.98204 & \\
\hline \multicolumn{5}{|c|}{ Normalized cointegrating coefficients (standard error in parentheses) } \\
\hline IR & INF & & & \\
\hline \multirow[t]{2}{*}{1.000000} & -1.465870 & & & \\
\hline & $(0.26836)$ & & & \\
\hline \multicolumn{5}{|c|}{ Adjustment coefficients (standard error in parentheses) } \\
\hline \multirow[t]{2}{*}{$\mathrm{D}(\mathrm{IR})$} & 0.903081 & & & \\
\hline & $(0.25028)$ & & & \\
\hline \multirow[t]{2}{*}{ D(INF) } & 0.700996 & & & \\
\hline & $(0.54300)$ & & & \\
\hline
\end{tabular}

Source: Author's Calculation 
Response to Cholesky One S.D. Innovations \pm 2 S.E.

Response of IR to IR

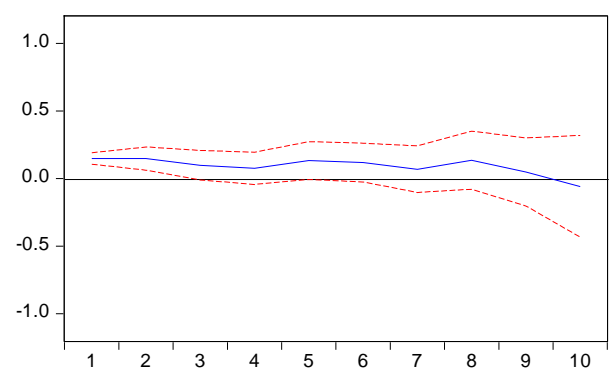

Response of INF to IR

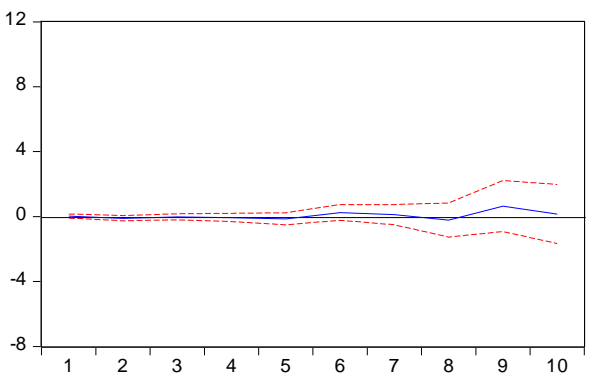

Response of IR to INF

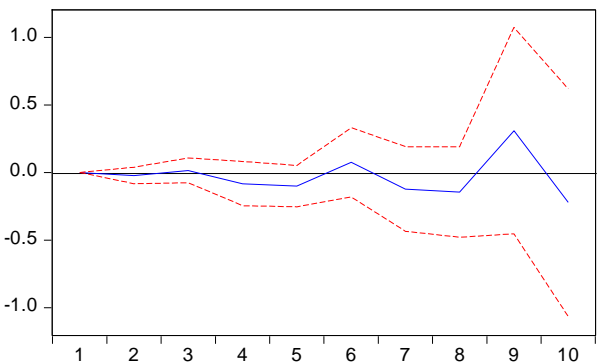

Response of INF to INF

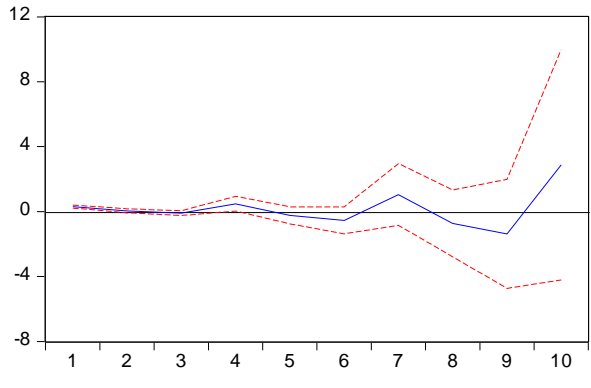

Fig-1

Source: Author's Calculation Variance Decomposition

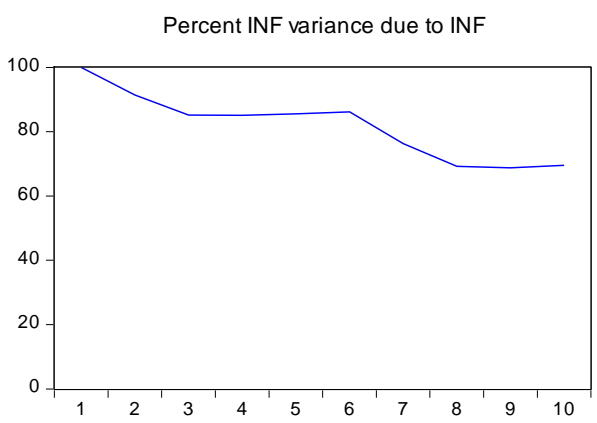

Percent INF variance due to IR



Percent IR variance due to INF

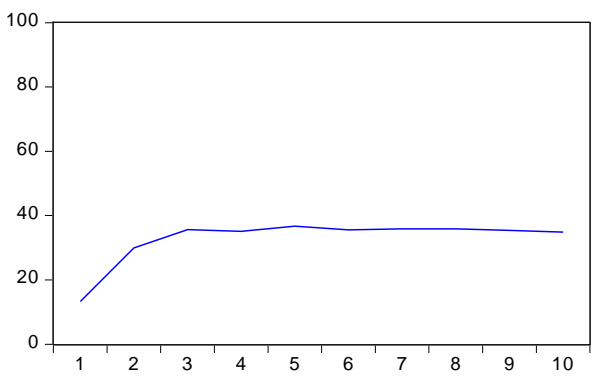

Fig-2

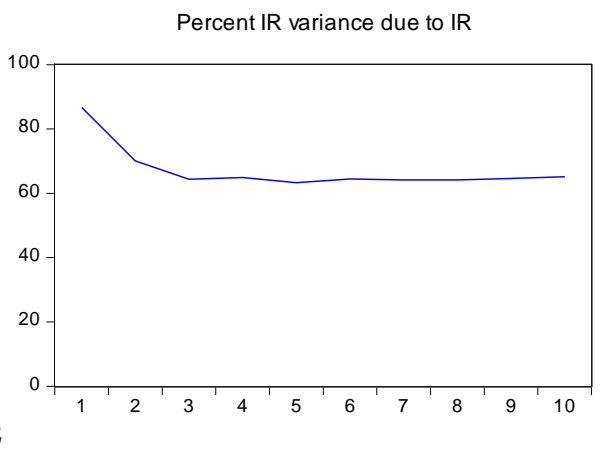

Source: Author's Calculation

\section{CONCLUSION AND POLICY IMPLICATION}

This study investigated the causality between interest rate and inflation of United Kingdom on annual data from 1988 to 2017 and for empirical analysis Granger Causality test is used. Chi- square statistics were used to predict the direction. The results confirm that there is bilateral and feedback causality among interest rate and inflation of United Kingdom. So, both variables are causing or influencing each other especially in short run but in long run interest rate might not cause inflation because at fourth lag we found significant at $5 \%$. These results are similar to the result obtained by Mishkin [13]. So, the recommendation for the policy maker is that interest rate control inflation in short run but in long run other measured must also be taken to control inflation in other words the result support the views of Carlson [12]. 
Funding: This study received no specific financial support.

Competing Interrests: The author declare that there is no competing interest.

\section{REFERENCES}

1. Svensson, L. E., \& Leiderman, L. (Eds.). (1995). Inflation Targets. Centre for Economic Policy Research.

2. Bernanke, B. S., \& Mihov, I. (1998, December). The liquidity effect and long-run neutrality. In Carnegie-Rochester conference series on public policy (Vol. 49, pp. 149-194). North-Holland.

3. Cagan, P. (1956). The Monetary Dynamics of Hyper-Inflation in Friedman, M. (ed.), Studies in the Quantity Theory of Money, University of Chicago Press, Chicago.

4. Sargent, T. J. (1969). Commodity Price Expectations and the Interest Rate, in: Gibson, W. E., \& Kaufman, G. G. (ed.), Monetary Economics: Readings on Current Issues, Mc Graw Hill Book Co, NY.

5. Gibson, W. E. (1970). Price-expectations effects on interest rates. The Journal of Finance, 25(1), 19-34.

6. Muth, J. F. (1961). Rational expectations and the theory of price movements. Econometrica: Journal of the Econometric Society, 29:315-335.

7. Malkiel, B. G., \& Fama, E. F. (1970). Efficient capital markets: A review of theory and empirical work. The journal of Finance, 25(2), 383-417.

8. Lahiri, K., \& Lee, J. (1979). Tests of Rational Expectations and Fisher Effect. Southern Economic Journal, 413-424.

9. Levi, M. D., \& Makin, J. H. (1979). Fisher, Phillips, Friedman and the measured impact of inflation on interest. The Journal of Finance, 34(1), 35-52.

10. Carlson, J. A. (1977). Short-term interest rates as predictors of inflation: Comment. The American Economic Review, 67(3), 469-475.

11. Nelson, C. R., \& Schwert, G. W. (1977). Shortterm interest rates as predictors of inflation: On testing the hypothesis that the real rate of interest is constant. The American Economic Review, 478486.

12. Carlson, J. A. (1977). Short-term interest rates as predictors of inflation: Comment. The American Economic Review, 67(3), 469-475.

13. Mishkin, F. S. (1984). Are real interest rates equal across countries? An empirical investigation of international parity conditions. The Journal of Finance, 39(5), 1345-1357.

14. MacDonald, R., \& Murphy, P. D. (1989). Testing for the long run relationship between nominal interest rates and inflation using cointegration techniques. Applied Economics, 21(4), 439-447.

15. Mishkin, F. S. (1992). Is the Fisher Effect for Real? A Re examination of the Relationship between Inflation and Interest Rates. Journal of Monetary Economics, 30:195-215.

16. Wallace, M. S., \& Warner, J. T. (1993). The Fisher Effect and the Term Structure of Interest Rates: Tests of Cointegration. Review of Economics and Statistics, 75:320-324.

17. Mishkin, F. S., \& Simon, J. (1995). An Empirical Examination of the Fisher Effect in Australia, NBER Working Paper No.5080, NBER, MA

18. Johansen, S., \& Juselius, K. (1990). Maximum Likelihood Estimation and Inference on cointegration - with Applications to the Demand for Money, Oxford Bulletin of Economics and Statistics, 52:169-210.

19. Rose, A. K. (1988). Is the Real Interest Rate Stable? Journal of Finance, 43:1095-1112.

20. Paul, F. H., Ali, S. R., Soomro, R., Ali, Q., \& Abbas, S. K. (2018). Exchange Rate Volatility and Economic Growth: Evidence from Kuwait. Eurasian Journal of Analytical Chemistry. 13(6):emEJAC181130.

http://www.eurasianjournals.com/Exchange-RateVolatility-and-Economic-Growth-Evidence-fromKuwait, 104469,0,2.html

21. Mustafa, K., \& Ali, S. R. (2018). The Macroeconomic Determinants of Remittances in Pakistan. International Journal of Business Management and Finance Research, 1(1), 1-8. http://www.academiainsight.com/index.php/26415313/article/view/25

22. Abbas, S. K., Fazal, A., Ali, S. R., \& Faisal, N. (2019). Revaluation of Fixed Assets and Future Firm Performance: Evidence from Cement Sector of Pakistan. Journal of Computational and Theoretical Nanoscience. 16, 5-6, 2233-2236(4). https://www.ingentaconnect.com/contentone/asp/jc tn/2019/00000016/f0020005/art00080\#Refs

23. Khan, S., \& Ali, S. R. (2019). Time Series Analysis of Aggregate Export Demand of Pakistan. RADS Journal of Business Management. 1(1): $\quad$ 31-37. http://jbm.juw.edu.pk/index.php/jbm/article/view/3

24. Peng, W. (1995). The Fisher Hypothesis and Inflation Persistence Evidence from Five Major Industrial Countries, IMF Working Paper /95/118, IMF, Washington D.C.

25. Hess, P. J., \& Bicksler, J. L. (1975). Capital asset prices versus time series models as predictors of inflation: The expected real rate of interest and market efficiency. Journal of Financial Economics, 2(4), 341-360. 